\title{
Uracil-DNA Glycosylase
}

National Cancer Institute

\section{Source}

National Cancer Institute. Uracil-DNA Glycosylase. NCI Thesaurus. Code C106308.

Uracil-DNA glycosylase (313 aa, $\sim 35 \mathrm{kDa}$ ) is encoded by the human UNG gene. This protein plays a role in DNA metabolism. 